\title{
Crafting Crisis Narratives
}

\begin{abstract}
Communication is pivotal when a society faces a sudden, disruptive and disturbing event. People want to know what is going on, why it is happening, what is done to safeguard them and what they can to protect themselves. During COVID-19, governments were the main sources of that information, at least initially. Governments tried to shape the attitudes, emotions and behaviours of citizens in accordance with their policies. Over time, alternative crisis narratives emerged and influenced citizen behaviour. This chapter examines crisis communication in the COVID-19 crisis: how did leaders try to 'make making' of this unprecedented threat? How did they deal with the alternative crisis frames that emerged over time?
\end{abstract}

Keywords Crisis communication - Crisis narratives - Framing contests . Meaning making $\cdot$ Leadership credibility $\cdot$ Public trust

My father was left to die alone, at home, without help. We were simply abandoned. No one deserves an end like that-Bergamo, Italy resident Silvia Bertuletti, 5 April 2020 (NDTV, 2020)

This is a test for our solidarity, our common sense and care for each other. And I hope we pass the test-German Prime Minister Angela Merkel, televised press conference, 11 March 2020 (BBC, 2020) 
Bill Gates will use microchip implants to fight coronavirus, as he revealed during a Q\&A on Reddit, 19 March 2020. (Biohackinfo News, 2020)

The Covid-19 epidemic can teach us a lot about ourselves and our civilization. It reminds us, first of all, of the deep human vulnerability in a world that has done everything to forget it-French philosopher Corine Pelluchon, 23 March 2020 (Legros, 2020)

\section{Constructing the Meaning of the COVID-ig Crisis}

A bitter complaint about institutional failure wrapped in a jarring story of personal suffering. A confident assertion of a conspiracy theory. A leader making a moral appeal to the better angels of our nature. A philosopher using the pandemic to remind us of our fundamental needs and frailties. How to get everybody on the same page? Is it really important to do that? Four different opening quotes, four different interpretations of the COVID-19 crisis.

Public communication is pivotal when societies face a disruptive, disturbing and threatening event. People want to know what is going on, why it is happening, what is done to safeguard them and what they can do to protect themselves. Governments are expected to provide that information. They package the information in words that form narratives. They try to influence how citizens create meaning around the events that threaten them. We refer to this process in terms of 'meaning making' (Boin et al., 2008, 2016).

Meaning making serves different goals and can have unintended (and undesirable) consequences. The instrumental function of meaning making is to provide a persuasive narrative that encourages people to support (or question) specific policy choices. The empowering function of meaning making is to help people make informed crisis response decisions. Its political function is to underpin claims about legitimacy: to foster, restore or challenge public trust in public authority figures and public confidence in institutions, systems and processes.

It is by no means a simple communication task. What makes it a complex process is that governments are not the only actors trying to 'make meaning' of a crisis. The broad consensus to 'take the politics out of this' that typically prevails during the acute stage of a major emergency gives way to division and politicization once the most urgent sense of threat has receded (Boin et al., 2008; Kaniasty \& Norris, 2004). 
The online universe offers limitless possibilities to exercise voice. Politicians, stakeholders, victims, journalists, expert commentators, lawyers, social influencers and protest groups will promote a wild variety of crisis narratives that challenge those forwarded by government authorities and subject matter experts. In this fragmented, real-time communication environments, authorities have very little time to first make sense of a crisis internally before communicating a narrative that dominates and fulfils the three functions outlined above.

In this chapter, we discuss how leaders 'made meaning' around the COVID-19 crisis. A basic policy and communicative dilemma bedevilled many government leaders during this pandemic. They had to do their utmost to prevent people from becoming sick and to save as many lives as possible. They had to weigh public health risks against the socio-economic impacts of lockdown measures. To influence collective behaviour-critically important, as we saw in the previous chapter-leaders had to be effective in explaining how they dealt with this dilemma. Many leaders wrestled with the challenge, with various degrees of success. Some failed miserably or did not even try (it is hard to see the difference from afar). Some leaders shone and were also highly effective in suppressing the virus.

\section{The Rise and Fall of Crisis Narratives}

The Dutch government initially rode a wave of public support. The public mood of shock after the first social distancing measures was immediately followed by an outpouring of prosocial behaviour. The high level of compliance with imposed restrictions was widely considered the result of Prime Minister Rutte's meaning-making skills. In a powerful speech to the nation, Rutte emphasized collective solidarity, voluntary compliance and admiration for the 'heroes' of the first-line medical response. A regime of frequent press conferences and parliamentary briefingsperformed mostly by the prime minister, the senior health minister and the chair of the Outbreak Management Team-resonated strongly. Millions tuned into the televised press conferences. The government's messaging dominated the airwaves as well as social media.

The national consensus dissipated with the first wave. Once the acute health threat had receded, critics began to nibble at the government's narrative. They started asking poignant questions. Why had the spread of the virus come as a surprise? How could it run rampant in the nursing homes, killing so many elderly? Why had we not stockpiled critical medical 
supplies? Why had we allowed our health system to become so lean and efficient that it lacked the requisite IC capacity-essential for any largescale disaster? Why did it take such a long time to ramp up testing capacity? Why did national leaders and experts so adamantly oppose the use of face masks? Why were the schools closed (when experts had advised against it)? Were all those measures really necessary? Could the government not have relaxed measures a bit sooner?

Questions gave rise to counter-narratives. One narrative suggested that the Dutch government had failed to act in time, and another claimed that the imposed lockdown had been unnecessary. These narratives were illustrated with stories of other nations that had done better on infection counts and mortality rates. In both types of narratives, experts had read the situation all wrong and leaders had failed to see the obvious.

The competing crisis narratives emerged as non-compliance with social distancing measures increased. Government ministers reacted with harsh comments, breaking with the government's reliance on 'soft power' and nudging. Protest groups formed, some rapidly gaining a noisy following. Social media started to fill with messages of despair, frustration, anger and mistrust. Conspiracy theories made the rounds on internet. The government's proposed emergency legislation, extending its executive powers, met with resistance from an unlikely combination of legal scholars, left-leaning social activists and conservative libertarians. With a national election looming in March 2021, government measures and the narrative underpinning were increasingly scrutinized and contested.

And then the second wave hit. Prime Minister Rutte and his team thought they could appeal to common sense and solidarity, which had worked so well in quelling the first wave. But the tried-and-trusted narrative no longer worked. People had learned that the risk of becoming ill was very low for most. The cacophony of expert advice made it easy for people to pick and choose the explanation they liked best. When Dutch leaders sharpened their tone, they met a wall of derision ("they are blaming the citizens again"). After several tries to reign in collective behaviour, the government finally resorted to a lockdown that was much stricter than the one imposed during the first wave.

And so it was, mutatis mutandis, in many other countries: initial surges in support and corresponding successes, but also dominant narratives encountering a growing sense of unease, concern and contestation. Countries that were also experiencing major 'second waves' and thus prolonged or renewed restrictions were seeing growing 'reactance' to government 
messaging (Frailing \& Harper, 2017). In some countries-the US and the UK come to mind-the progression to politicization and frame conflicts was rapid and steep.

But other countries saw remarkably high levels of sustained agreement about the nature of the challenge, the values that should be prioritized and the broad thrust of the emergency measures taken. This did not just happen in countries where the curve was flattened rapidly, such as South Korea and New Zealand, but also in hard-hit jurisdictions like Sweden or Mexico.

Many factors affect the perception of governance success in a crisis like COVID-19 (Bromfield \& McConnell, 2020). The massive problems in their health systems, the socio-economic consequences of the crisis regime, tensions within ruling parties and intergovernmental relations, the timing of the pandemic in relation to the electoral cycle (in the US), the dynamics of a pre-existing crisis (Brexit, in the UK)-these were undoubtedly factors at play in this or that country. Culturally contingent attitudes to risk, loss and institutional failure also weigh into the narratives that will be told about this catastrophe (Bovens \& 't Hart, 1996; Douglas \& Wildavsky, 1982; Green, 1997).

A critically important factor, as we argue in this chapter, is the communicative performance of leaders and the congruence between their words and their governments' deeds (cf. Brunsson, 1989; Mintrom \& O'Connor, 2020). To be effective, leaders have to win the 'framing contests' (Boin et al., 2009) in which politicians, journalists, stakeholders, technical experts and social media gurus participate with so much gusto.

Government elites once enjoyed some a priori advantages in these contests, due to their access to vital information, highly used and trusted communication channels, and the support of specialized advisers. But their 'standing' among large parts of the public, often low to begin with, and possibly further attenuated by the occurrence of unsettling events has created a more even playing field (Ignatieff, 2012, pp. 114-135). It provides critics of the government response with opportunities to influence people who have become receptive to 'counter frames' (because they are, for instance, dismayed to discover that governments are bungling their responses). 


\section{The POWer of Words}

Spector (2020) reminds us that the word "crisis" is a label. Crises are socially constructed phenomena. The claim that a particular set of events and circumstances constitutes a crisis is "always an assertion of power and an expression of interests", as the "facts [of the events] never speak for themselves... [and] always await the assignment of meaning" (Spector, 2020 , p. 305). Through active communication (or refraining from it), political leaders try to stick the label on a situation-or they actively work against labelling this or that situation as a crisis.

The vocabulary of crisis communication can be thought of as a layered cake. Each layer contains higher levels of complexity, ambiguity and political import. The bottom layer consists of terms like 'flood', 'earthquake' 'explosion', 'demonstration', 'wildfire', 'bankruptcy', 'explosion', 'collision', 'exodus', 'drought' and 'hostage-taking'. They offer relatively straightforward descriptors of non-routine events in the physical world. They often dominate early media reports of newly occurring disruptions. They provide levers for 'placing' the basic features of events into the public consciousness. They can be purposefully used to provide relatively detached, factual, de-politicized accounts of events. For that reason, they are part and parcel of the meaning-making repertoires of operational agencies and technical experts.

The second layer consists of interpretative labels used to frame the situation cognitively, emotionally and politically. This layer includes terms like 'incident', 'accident', 'disaster', 'riot', 'scandal', 'fiasco', 'catastrophe' and 'tragedy'. These words help to tell stories. They allow the storyteller to appeal to commonly held cognitive and emotional scripts. Some of these ostensibly descriptive terms are, in fact, full of normative content, and thus politically consequential in that they portray actors and events in particular ways and convey value judgements. Think of: 'cover up', 'freedom fighters', 'terrorists', 'heroes', 'red tape', 'incompetence' and 'mismanagement'. The adjectives used matter greatly, too. Denoting those who partake in Black Lives Matters manifestations as 'peaceful protestors' or 'dangerous radicals' or government responses to a disaster as 'bungled', 'bureaucratic', 'coordinated' or 'agile' reflects different vantage points and different strategic intent on the part of the speakers.

The third layer consists of explicit crisis language. Over time, the term crisis has acquired a host of meanings and has been broken down into 
numerous typologies. In the medical world, a crisis marks the stage in an illness where the patient either improves markedly or worsens and possibly dies. In other words, crisis as a fork in the road. Likewise, in the Chinese language, the character 危机(Wéijī) combines terms referring to danger or precariousness, and 'changing point'. Such ambiguity is absent in political parlance. In the political world and in media discourse, describing a community, a public issue or a government project, policy or organization as being 'in crisis' signals serious trouble: something drastic needs to be done urgently to counter the threat and contain the damage.

Applying the crisis label is not mere wordplay. Crisis talk matters. It opens the door to 'claims of urgency' (Spector, 2019): calls for urgent measures and urgent questioning of the system's safety, reliability and integrity. The crisis label implies an urgent promotion of action, packaged in a critique of the beliefs, values and interests underpinning 'the way things get done around here'. Crisis talk provides language that can be used to convey the existence of threats to the common cause. It also offers a semantic platform for launching appeals to reconfirm, repair, reform or repudiate the systemic status quo. The effective use of crisis language moves the relevant system (s) into a critical juncture, a moment to reconsider what it is, what it does and what it could or should do and how it should adapt and change.

Table 4.1 maps the architecture of meaning making in times of disruption. It juxtaposes 'physical' event characteristics, the key rhetorical tropes that tend to be present in the accounts of actors and observers, and the (intended and unintended) meaning-making implications of these framing efforts. It is important to note that the three columns are loosely coupled-the three types of talk are deployed to construct believable links between events and the meanings attributed to the events by actors, stakeholders and publics alike.

\section{Framing Contests}

In any given crisis, multiple accounts of the what, where, who, how and what are on offer. But only a limited number of recurring storylines constitute the heart of the framing contest. Political leaders follow remarkably similar framing trajectories (cf. Kuipers \& Brändström, 2003). According to De Vries (2004, p. 612), officials "will always try to avoid a framework in which they are personally held responsible" (...). They will try to frame a crisis or disaster "in terms of a natural framework. If 
Table 4.1 Meaning making in disruptive times: a roadmap

\begin{tabular}{|c|c|c|}
\hline & $\begin{array}{l}\text { Meaning-making layers } \\
\text { Descriptive talk } \\
\text { Interpretive talk } \\
\text { Crisis talk }\end{array}$ & \\
\hline Event characteristics & Narrative tropes $\longrightarrow$ & $\begin{array}{l}\text { Meaning-making } \\
\text { implications }\end{array}$ \\
\hline $\begin{array}{l}\text { Nature of the } \\
\text { threat/damage }\end{array}$ & $\begin{array}{l}\text { This is what is happening } \\
\text { This is what is at stake here }\end{array}$ & $\begin{array}{l}\text { Threat perception \& level of } \\
\text { arousal } \\
\text { Salient values, norms, } \\
\text { commitments, interests }\end{array}$ \\
\hline $\begin{array}{l}\text { Locus and scope of } \\
\text { threat/damage }\end{array}$ & $\begin{array}{l}\text { This is how bad it is } \\
\text { This is who and what are } \\
\text { impacted }\end{array}$ & $\begin{array}{l}\text { Sense of loss, fear, relief } \\
\text { Sense of ownership, } \\
\text { involvement, } \\
\text { Intergroup solidarity and } \\
\text { conflict }\end{array}$ \\
\hline $\begin{array}{l}\text { Agent of } \\
\text { threat/damage }\end{array}$ & $\begin{array}{l}\text { This is how it could happen } \\
\text { This is who are responsible }\end{array}$ & $\begin{array}{l}\text { Causal beliefs } \\
\text { Accountability beliefs } \\
\text { Ingroup/outgroup } \\
\text { constructions } \\
\text { Trust in system, institutions, } \\
\text { elites }\end{array}$ \\
\hline Future contingencies & $\begin{array}{l}\text { This is what could happen } \\
\text { next }\end{array}$ & $\begin{array}{l}\text { Expectations, fears and hopes } \\
\text { Perceived sense/locus of } \\
\text { control }\end{array}$ \\
\hline $\begin{array}{l}\text { Interventions and } \\
\text { consequences }\end{array}$ & $\begin{array}{l}\text { This is what must be done to } \\
\text { respond \& recover } \\
\text { This is how to obtain redress } \\
\text { and create closure } \\
\text { This is how we need to learn } \\
\text { \& improve moving forward }\end{array}$ & $\begin{array}{l}\text { Perception of effectiveness and } \\
\text { fairness of government } \\
\text { responses } \\
\text { Desire to punish perpetrators, } \\
\text { mistake-makers } \\
\text { Appetite for socio-political } \\
\text { change } \\
\text { Motivation to 'move on' }\end{array}$ \\
\hline
\end{tabular}

this is not possible, they will try to blame the disaster on the policy". In other words, they will emphasize exogenous causes, moving the onus of accountability away from them.

That type of storyline emphasizes exogenous forces of geography, weather, foreign powers, higher levels of government, international markets, multinational corporations and technological dependencies. It points to the many hands syndrome by explaining that the events in question are the product of complex systems and processes traversing geographical, jurisdictional, hierarchical and disciplinary boundaries; it 
follows that 'no one' (no single point of authority and control) is in charge (Bovens, 1998). It reminds audiences of the limits of hierarchical or political control that leaders and managers can exercise: it is impossible to monitor and prevent each human error of operational staff and first-line management (Reason, 1990). It highlights the unforeseeability of the crisis, pointing towards the "unknown unknowns" that lurk in any system, and more so in large, dynamic, transboundary, non-linear systems (Perrow, 1999).

The political upshot of these narratives is that they serve to deescalate, exculpate elites and divert attention towards deeper flaws and tensions in the institutional design and power realities of the existing system. They direct negative emotions about what is happening and why it is happening down (to lower-level staff), out (to other actors, sectors, foreign powers, known enemies) and, depending on the narrator's vantage point, $u p$ (senior management, corporate 'fat cats', international institutions). The indirect message is that people should be happy that the leader is willing to assume the task of crisis management when all these forces are conspiring against the leader.

The French President, Emmanuel Macron, made liberal use of military metaphors to communicate not only the gravity of the threat but also his government's resolve to prioritize the health and safety of his citizens. Macron's rhetorical style befitted the historical script of the Fifth Republic's presidency. No doubt inspired by his illustrious predecessor, General Charles de Gaulle,

Macron consistently developed a "war" framework, designating the virus as an enemy. This type of framing suggests that the attacking force originates outside society. The President thus declared a "general mobilisation" on March 12, de described crisis management as a war effort on March 16, and further refined this line of argument in his March 20 address, which is entirely structured around war metaphors: deceased nurses "falling" during the crisis, a response organised around "lines [of defense]", "the children of the nation" "fighting" against the virus. The President's speeches call for a "national unity" to defend the nation. (Brandt \& Wörlein, 2020)

At the other end of the meaning-making continuum, we find a cluster of interpretive frames that endogenise the causes of crisis. These are, in essence, accusatory narratives. They resist the idea that negative events are 'Acts of God', isolated incidents or other people's faults. These frames 
problematize the crisis as a symptom of endemic, or underlying, problems. Instead of getting elites off the hook, they put them in the spotlight. Instead of obfuscating issues of power, privilege, inequality and injustice, these accounts highlight them.

These narratives do not legitimate response and recovery strategies that seek to restore the status quo. They rather suggest a dire need for learning, change and reform. In their most trenchant form, they advocate wholesale repudiation of the status quo: think of (neo-)Marxist and critical theory accounts of recessions, welfare state problems and other 'crises of capitalism' (Habermas, 1975; Kliman, 2011; Offe, 1976) or calls for a complete abandonment of intrinsically dangerous industries (Perrow, 1999).

Endogenous crisis narratives animate an activist politics of investigation, accountability and blame that is often welcomed by those who are on the outer edge of the system and those who have felt powerless to change it. When widely given credulity, endogenous crisis narratives can generate public anxiety and anger (Coombs et al., 2010; Jin, 2010). As these emotions will find political expression one way or the other, endogenous crisis narratives can cause serious problems for governing elites (Boin et al., 2008).

News outlets will relentlessly focus on deficiencies and blind spots in existing policies, plans, preparations, training and resourcing, serving up dramatic examples of poor information-sharing and miscommunication between policymakers, agencies and levels of government. More fuel is added when social media fill with conspiratorial accounts in which the crisis is explained as the outcome of deliberately engineering by malevolent elites pursuing pernicious agendas, under cover of the 'fake news' media. All this creates an atmosphere in which large constituencies no longer know who or what to believe and lose trust in experts, policymakers, and the systems and processes governing their lives (cf. Krause et al., 2020; Oyeyemi et al., 2014; Van Prooijen \& Douglas, 2017).

\section{Winning Factors?}

The outcome of the contest between competing crisis narratives is hard to predict. Why can governments sometimes 'control the narrative' almost without challenge, whereas in other occasions narrative dominance eludes them entirely (Olsson \& Nord, 2015; You \& Ju, 2019)? 
We can offer some plausible inferences (Boin et al., 2009; Coombs, 2015). One revolves around the placement of a crisis in political time: governing elites are more likely to lose the battle when the crisis unfolds towards the end of an electoral cycle, or when it follows on the back of a recent or otherwise vividly remembered historical precedent. Another is media slant: when key news media have already turned highly critical about incumbent elites, any new incident will help to push 'endogenized' crisis narratives. A third concerns duration: it is much more difficult for governments (or any other actors) to achieve and maintain meaningmaking dominance in protracted, slow-burning crises as opposed to relatively short and episodic ones (Boin et al., 2021; cf. 't Hart \& Boin, 2001).

The strategies and conduct of the people and groups engaging in crisis communication remain a crucial factor, whether they be political leaders and top officials (Boin et al., 2010; Jong, 2017; Masters \& 't Hart, 2012), corporate CEOs and communication professionals (Coombs, 2007; Coombs \& Holladay, 2006; Hearit, 2006), media outlets (Olsson et al., 2015), celebrity activists (Marsh et al., 2010; Richey \& Budabin, 2016), social influencers (Enke \& Borchers, 2019) or social media users at large (Austin \& Jin, 2017; Vos \& Buckner, 2016).

Why do they 'win' or 'lose' crisis-framing contests? This question opens the door to the other questions. What was their reputation and credibility prior to the crisis? What rhetorical styles do they employ? What framing, casting, scripting techniques do these use? What forms of non-verbal communication do they engage in? Do they instigate or participate in public rituals of grieving, protest, animosity, conciliation, remembrance? Do they show empathy (Dryhurst et al., 2020; 't Hart, 1993)? When and how often do they communicate? How does their messaging evolve over time? What channels do they use, and how do they adapt the content and the style of their messaging to those channels? How do they respond to criticism and accusations (denials, admissions, excuses, apologies)? Do they go at it alone, or do they engage in jointly crafted and communicated crisis framing?

We should also look at the 'receiving audiences' to understand how people 'make meaning' of a crisis over time, both individually (Park, 2016) and collectively (Fischer-Pressler et al., 2019; Hirschberger, 2018). Which messaging and which speakers draw the attention of mass publics? 
Who is believed and who is mistrusted by which audiences? Which narratives are adopted and repeated in the deliberations of political forums (Vliegenthart \& Damstra, 2019)?

The mountain of research findings that has been produced has not as yet added up to robust theories that can explain and predict the dynamics and outcomes of political crisis communication. But it does provide us with analytical tools to examine the meaning-making dynamics of COVID-19, which we will do next.

\section{Making Meaning of COVID-i9}

From a meaning-making perspective, the pandemic had a combination of features that made it particularly challenging to impose authoritative crisis narratives. One such feature is its unusually long duration. At the time of writing, the threat had been 'live' for almost a year with no immediate end in sight. Maintaining the public's attention and preserving government credibility proved a hard challenge for many government leaders. Whether it was on the infectiousness and lethality of the virus, the effects of face masks and school closures, the relative merits of compulsory versus voluntary containment regimes, the prospective benefits of contact-tracing technologies or the social, economic, political and geostrategic impacts of the crisis, each layer of meaning making-factual accounts, causal interpretations, accountability claims and 'what-now' narratives-had to be adapted with each shift in the balance of intended and unintended consequences of earlier crisis responses.

In countries like Norway, where high levels of public trust in government combined with swift and successful responses to the first wave, crisis communication was relatively straightforward (Christensen \& Laegreid, 2020). Yet, regardless of the success in dealing with the first wave, community scepticism, a sense of loss and social distress gave rise to counter-narratives as the social costs of the imposed crisis regime mounted. Unease about the use of emergency powers and the quality of democracy found expression in high-profile demonstrations, legal challenges, critical reports by legal scholars and human rights groups, as well as 'robust' discourse across both the traditional and social media (Bieber, 2020; Seyhan, 2020).

Conspiracy theories emerged with regard to the origins of the virus and the 'agendas' that were purportedly served by the pandemic (Islam et al., 2020). Donald Trump's 'China virus' label came and went relatively 
quickly, but other conspiratorial accounts-featuring, among others, Bill Gates, George Soros, Big Pharma and the Deep State-gained traction well beyond the fringe networks where they originated (Centers for Disease Control and Prevention, 2020; Mian \& Khan, 2020). The appeal of these conspiracy accounts was particularly strong in countries or among groups with low trust in public institutions. Early 'misinformationbusting' efforts by the UN, the WHO and the CDC made no inroads (e.g. WHO, 2020).

Even as scientists kept amassing knowledge about the virus at an impressive and possibly unprecedented rate, uncertainty about the virus, its impacts and the best response persisted and deepened. This created a sense-making vacuum that opened the door to information warfare. The editors of The Lancet (2020) referred to an 'infodemic'. Authorities have found it increasingly difficult to explain and justify their policies by pointing to the scientific authority of their expert advisers. Early-stage deference to expertise gave way to widespread questioning of that expertise (Perry et al., 2020). Claims such as 'they know best' or 'this has proven to work' lost their appeal over time.

This erosion of government ability to craft authoritative narratives was exacerbated by different experts saying different things, a logical and usually desirable result of the institutional fragmentation of scientific expertise. In open societies, anyone with medical or science credentials could find platforms on which to question the evidence base underpinning official narratives about testing, rules and practices of social distancing, the effectiveness of lockdowns and facemasks, the wisdom of school closures, and the expected timing and safety of vaccines (Camargo, 2020; Reiss \& Bhakdi, 2020).

The protracted duration of the crisis and the pervasive uncertainty gave room for an unusual factor to play out in full: the impatience of Modern Man. In fast-burning crises, impatience rarely plays a role of importance. In the COVID-19 crisis, impatience with the duration of the crisis regime, the slow roll-out of the vaccines and the growing perception of governmental incompetence (justified or not) posed new communication challenges for leaders. To 'see light at the end of the tunnel' was not enough. Citizens and business owners wanted to know when the crisis would end. Even vague promises would be employed as markers of progress, which undermined the willingness of leaders to make any promises. 
The COVID-19 crisis had to be managed without a roadmap. Most government leaders and scientists studiously and sensibly avoided pinning themselves down on the million dollar question of 'when will there be a vaccine?' Governments made do with placeholder notions such as 'the new normal' or the ' 1,5 meter society' and by replacing one time-limited set of support package with another. As beacons for longer-term expectations and strategic decision-making, these notions were of limited use. When the vaccines finally (and quite suddenly) materialized, government leaders wrestled with the vagaries of a massive roll-out and the escalating patience of various groups demanding priority in the vaccination process.

The transboundary and global nature of the pandemic created a social laboratory for comparing and rhetorically 'benchmarking' pandemic responses (cf. Baekkeskov, 2015). It provided critics with ample ammunition in their questioning why 'we' were not doing what 'they' were doing. Since there were so many variables to consider, so many data points available (Cheng et al., 2020) and so many pandemic response regimes involved, countless comparisons could be drawn, suited to the comparators' purposes and proclivities (Anderssen et al., 2020; Capano et al., 2020; Greer et al., 2020).

'Outlier' jurisdictions whose policy settings or leadership rhetoric differed markedly from those of other governments invited intense coverage, analysis and commentary worldwide (Ortega \& Orsini, 2020). The crisis responses of female government leaders and chief health officers were favourably compared to those of male counterparts, invoking infection rates and deaths as evidence. It was powerful rhetoric, but questionable science (e.g. Cherneski, 2020; Sergent \& Stajkovic, 2020). Debates about school closures and the use of facemasks inevitably referenced experiences in other countries.

Sweden's COVID-19 experience featured in many comparisons (Irwin, 2020). At least six narratives emerged during the first few months, each of which was misleading in one way or another: (1) life is normal in Sweden, (2) Sweden has a herd immunity strategy, (3) Sweden is not following expert advice, (4) Sweden is not following WHO recommendations, (5) the Swedish approach is failing and (6) Swedes trust the government (cf. Nygren \& Olofsson, 2020; Pierre, 2020). In similar vein, the performance of countries such as South Korea, Vietnam, Australia and New Zealand, which initially managed to prevent surging rates of infections or managed to 'flatten the curve' quicker than others, was (prematurely) framed as guiding 'examples' (Lee et al., 2020; Oh et al., 2020). 
Another guiding example was the meaning-making performance by the Prime Minister of New Zealand, Jacinda Ardern. A politically astute gunlaw reformer, Ardern had gained global recognition for her performance as a genuine and caring 'healer-in-chief' in the wake of the mass shootings at the Christchurch mosque. Ardern had become such a master of social media communication that her Facebook following alone was four times greater than those of the other seven main party leaders combined. She performed what has been dubbed 'a master class in political leadership' (Wilson, 2020) after the coronavirus landed on her country's doorstep (Kapitan, 2020).

\section{A Long Rollercoaster Ride}

Crisis communication is always a delicate business (Frandsen \& Johansen, 2020). Making meaning of the protracted COVID-19 mega-crisis has proven to be even harder still. Threats that morph. Uncertainties that do not abate. New uncertainties that arise. Unintended but inevitable negative consequences of control measures that hurt more and more. Public moods and risk equations that shift as a result. Actions taken by other governments and companies that cannot be controlled but affect one's constituents.

As curves were being flattened, acute public health fears subsided and the full extent of the losses sustained by communities and businesses sank in, government press conferences had to contend with more and louder voices of despair and dissent. Government claims were being challenged. The language of 'we' gave way to 'us and them'. Support gave way to rage, as lockdowns were being re-imposed in many places. In the framing contests between exogenous and endogenous accounts of what had happened and what it all meant, the latter gained prominence during the course of the crisis (Morgan, 2020).

When vaccinations started to make inroads, yet another round of complex meaning-making challenges emerged: how to maintain social discipline among the growing proportion of the population that can stop fearing the virus even as their economic prospects take a turn for the worse; how to craft believable narratives about the end of the crisis, the lessons to be learned and the futures that can be carved.

The roller coaster of COVID-19 meaning making will likely continue for years to come. 


\section{BIBLIOGRAPHY}

Anderssen, A. L., Hansen, E. T., Johannesen, N., \& Sheridan, A. (2020, May 15). Consumer responses to the COVID-19 crisis. VOX EU. https://voxeu. org/article/consumer-responses-covid-19-crisis.

Austin, L. L., \& Jin, Y. (2017). Social media and crisis communication. Routledge.

Baekkeskov, E. (2015). Transboundary crises: Organization and coordination in pandemic influenza response. In R. Dahlberg, R., O. Rubin, \& M. T. Vendelø (Eds.), Disaster research: Multidisciplinary and international perspectives (pp. 189-206). Routledge.

BBC. (2020, March 11). Coronavirus: Up to $70 \%$ of Germany could become infected-Merkel. https://www.bbc.com/news/world-us-canada-51835856.

Bieber, F. (2020). Global nationalism in times of the COVID-19 pandemic. Nationalities Papers, 1-13. https://doi.org/10.1017/nps.2020.35.

Biohackinfo News. (2020, March 19). Bill Gates will use microchip implants to fight coronavirus. https://biohackinfo.com/news-bill-gates-id2020-vaccineimplant-covid-19-digital-certificates/.

Boin, A., Ekengren, M., \& Rhinard, M. (Eds.). (2021). Understanding the Creeping Crisis. Palgrave.

Boin, A., McConnell, A., \& 't Hart, P. (Eds.). (2008). Governing after crisis: The politics of investigation, accountability and learning. Cambridge University Press.

Boin, A., 't Hart, P., \& McConnell, A. (2009). Crisis exploitation: Political and policy impacts of framing contests. Journal of European Public Policy, 16(1), 81-106.

Boin, A., 't Hart, P., McConnell, A., \& Preston, T. (2010). Leadership style, crisis response and blame management: The case of Hurricane Katrina. Public Administration 88(3), 706-723.

Boin, A., 't Hart, P., Stern, E., \& Sundelius, B. (2016). The politics of crisis management. Cambridge University Press.

Bovens, M. A. P. (1998). The quest for responsibility: Accountability and citizenship in complex organisations. Cambridge University Press.

Bovens, M., \& 't Hart, P. (1996). Understanding policy fiascoes. Transaction Publishers.

Brandt, P., \& Wörlein, J. (2020). Government communication during the Coronavirus crisis: Comparing France, Germany and the United Kingdom. SciencesPo. https://www.sciencespo.fr/cso/fr/content/government-crisiscommunication-during-coronavirus-crisis-comparing-france-germany-andunite.html.

Bromfield, N., \& McConnell, A. (2020). Two routes to precarious success: Australia, New Zealand, COVID-19 and the politics of crisis governance. 
International Review of Administrative Sciences. https://doi.org/10.1177/ 0020852320972465.

Brunsson, N. (1989). The organization of hypocrisy: Talk, decisions and action in organizations. Wiley.

Camargo, K. R. D., Jr. (2020). Trying to make sense out of chaos: Science, politics and the COVID-19 pandemic. Cadernos de Saúde Pública, 36(4), $1-7$.

Capano, G., Howlett, M., Jarvis, D. S. L., Ramesh, M., \& Goyal, N. (2020). Mobilizing policy (in)capacity to fight COVID-19: Understanding variations in state responses. Policy and Society, 39(3), 285-308.

Centers for Disease Control and Prevention. (2020, June 11). Reducing stigma. https://www.cdc.gov/coronavirus/2019-ncov/daily-life-coping/red ucing-stigma.html.

Cherneski, J. (2020). Evidence-loving rock star chief medical officers: Female leadership amidst COVID-19 in Canada. Gender, Work and Organization, 27(5), 1-16.

Cheng, C., Barceló, J., Hartnett, A., Kubinec, R., \& Messerschmidt, L. (2020). COVID-19 Government Response Event Dataset (CoronaNet v1.0). Nature Human Behaviour. https://doi.org/10.1038/s41562-020-0909-7.

Christensen, T., \& Laegreid, P. (2020). Balancing governance capacity and legitimacy: How the Norwegian government handled the COVID-19 crisis as high performer. Public Administration Review, 80(5), 774-779.

Coombs, W. T. (2007). Protecting organization reputations during a crisis: The development and application of situational crisis communication theory. Corporate Reputation Review, 10(3), 163-176.

Coombs, W. T. (2015). The value of communication during a crisis: Insights from strategic communication research. Business Horizons, 58(2), 141-148.

Coombs, W. T., Frandsen, F., Holladay, S. J., \& Johansen, W. (2010). Why a concern for apologia and crisis communication? Corporate Communications: An International Journal, 15(4), 337-349.

Coombs, W. T., \& Holladay, S. J. (2006). Unpacking the halo effect: Reputation and crisis management. Journal of Communication Management, 10(2), 123137.

De Vries, M. S. (2004). Framing crises: Response patterns to explosions in fireworks factories. Administration \& Society, 36(5), 594-614.

Douglas, M., \& Wildavsky, A. (1982). Risk and culture. University of California Press.

Dryhurst, S., Schneider, C. R., Kerr, J., Freeman, A. L. J., Recchia, van der Bles, A. M., Spiegelhalter, D., \& Van der Linden, S. (2020). Risk perceptions of COVID-19 around the world. Journal of Risk Research, 23(7-8), 994-1006.

Enke, N., \& Borchers, N. S. (2019). Social media influencers in strategic communication: A conceptual framework for strategic social media influencer 
communication. International Journal of Strategic Communication, 13(4), 261-277.

Fischer-Pressler, D., Schwemmer, C., \& Fischbach, K. (2019). Collective sensemaking in times of crisis: Connecting terror management theory with Twitter user reactions to the Berlin terrorist attack. Computers in Human Behavior, 100, 138-151. https://doi.org/10.1016/j.chb.2019.05.012.

Frailing, K., \& Harper, D. W. (2017). Toward a criminology of disaster: What we know and what we need to find out. Palgrave Macmillan.

Frandsen, F., \& Johansen, W. (Eds.). (2020). Crisis communication. De Gruyter.

Green, J. (1997). Risk and misfortune: The social construction of accidents. Routledge.

Greer, S. L., King, E. J., da Fonseca, E. M., \& Peralta-Santos, A. (2020). The comparative politics of COVID-19: The need to understand government responses. Global Public Health, 15(9), 1413-1416.

Habermas, J. (1975). Legitimation crisis. Beacon Press.

Hearit, K. M. (2006). Crisis management by apology: Corporate response to allegations of wrongdoing. Lawrence Erlbaum Associates.

Hirschberger, G. (2018). Collective trauma and the social construction of meaning. Frontiers in Psychology, 9(1441), 1-14.

Ignatieff, M. (2012). Fire and ashes: Success and failure in politics. Harvard University Press.

Irwin, R. E. (2020). Misinformation and de-contextualization: International media reporting on Sweden and COVID-19. Globalization and Health, 16(1), $1-12$.

Islam, M. S., Sarkar, T., Khan, S. H., Kamal, A. M., Hasan, S. M. M., Kabir, A., Yeasmin, D., Islam, M. A., Chowdhury, K. I. A., Anwar, K. S., Chughtai, A. A., \& Seale, H. (2020). COVID-19-related infodemic and its impact on public health: A global social media analysis. The American Journal of Tropical Medicine and Hygiene, 103(4), 1621-1629.

Jin, Y. (2010). Making sense sensibly in crisis communication: How publics' crisis appraisals influence their negative emotions, coping strategy preferences, and crisis response acceptance. Communication Research, 37(4), 522-552.

Jong, W. (2017). Meaning making by public leaders in times of crisis: An assessment. Public Relations Review, 43(5), 1025-1035.

Kaniasty, K., \& Norris, F. H. (2004). Social support in the aftermath of disasters, catastrophes, and acts of terrorism: Altruistic, overwhelmed, uncertain, antagonistic, and patriotic communities. In R. J. Ursano, A. E. Norwood, \& C. S. Fullerton (Eds.), Bioterrorism: Psychological and public health interventions (pp. 200-229). Cambridge University Press.

Kapitan, S. (2020, September 3). The Facebook prime minister: How Jacinda Ardern became New Zealand's most successful political influencer. The 
Conversation. https://theconversation.com/the-facebook-prime-ministerhow-jacinda-ardern-became-new-zealands-most-successful-political-influencer.

Kliman, A. (2011). The failure of capitalist production: Underlying causes of the Great Recession. Pluto Press.

Krause, N. M., Freiling, I., Beets, B., \& Brossard, D. (2020). Fact-checking as risk communication: The multi-layered risk of misinformation in times of COVID-19. Journal of Risk Research, 23(7-8), 1052-1059.

Kuipers, S., \& Brändström, A. (2003). From 'normal incidents' to political crises: Understanding the selective politicization of policy failures. Government and Opposition, 38(3), 279-305.

Lee, S., Hwang, C., \& Moon, M. J. (2020). Policy learning and crisis policymaking: Quadruple-loop learning and COVID-19 responses in South Korea. Policy and Society, 39(3), 363-381.

Legros, C. (2020, March 23). Coronavirus: "L'épidémie doit nous conduire à habiter autrement le monde". Le Monde. https://www.lemonde.fr/idees/art icle/2020/03/23/coronavirus-l-epidemie-doit-nous-conduire-a-habiter-aut rement-le-monde_6034049_3232.html.

Marsh, D., 't Hart, P., \& Tindall, K. (2010). Celebrity politics: The politics of the late modernity? Political Studies Review, 8(3), 322-340.

Masters, A., \& 't Hart, P. (2012). Prime ministerial rhetoric and recession politics: Meaning making in economic crisis management. Public Administration, 90(3), 759-780.

Mian, A., \& Khan, S. (2020). Coronavirus: The spread of misinformation. BMC Medicine, 18(89), 1-2.

Mintrom, M., \& O'Connor, R. (2020). The Importance of policy narrative: Effective government responses to Covid-19. Policy Design and Practice, 3(3), 205-227.

Morgan, M. (2020). Why meaning-making matters: The case of the UK Government's COVID-19 response. American Journal of Cultural Sociology, 8(2), 270-323.

NDTV. (2020). "We were simply abandoned": Hidden death count in Italy's COVID-19 crisis. NDTV. https://www.ndtv.com/world-news/coronaviruspandemic-hidden-death-count-in-italys-covid-19-crisis-as-many-die-at-home2206947.

Nygren, K. G., \& Olofsson, A. (2020). Managing the Covid-19 pandemic through individual responsibility: The consequences of a world risk society and enhanced ethopolitics. Journal of Risk Research, 23(7-8), 1031-1035.

Offe, C. (1976). 'Crisis of crisis management': Elements of a political crisis theory. International Journal of Politics, 6(3), 29-67.

Oh, J., Lee, J.-K., Schwarz, D., Ratcliffe, H. L., Markuns, J. F., \& Hirschhorn, L. R. (2020). National response to COVID-19 in the Republic of Korea and 
lessons learned for other countries. Health Systems \& Reform. https://doi. org/10.1080/23288604.2020.1753464.

Olsson, E.-K., \& Nord, L. W. (2015). Paving the way for crisis exploitation: The role of journalistic styles and standards. Journalism, 16(3), 341-358.

Olsson, E.-K., Nord, L. W., \& Falkheimer, J. (2015). Media coverage crisis exploitation characteristics: A case comparison study. Journal of Public Relations Research, 27(2), 158-174.

Ortega, F., \& Orsini, M. (2020). Governing COVID-19 without government in Brazil: Ignorance, neoliberal authoritarianism, and the collapse of public health leadership. Global Public Health, 15(9), 1257-1277.

Oyeyemi, S. O., Gabarron, E., \& Wynn, R. (2014). Ebola, Twitter, and misinformation: A dangerous combination? British Medical Journal, 349(g6178), 1-2.

Park, C. L. (2016). Meaning making in the context of disasters. Journal of Clinical Psychology, 72(12), 1234-1246.

Perrow, C. (1999). Organizing to reduce the vulnerabilities of complexity. Journal of Contingencies and Crisis Management, 7(3), 150-155.

Perry, S. L., Whitehead, A. L., \& Grubbs, J. B. (2020). Culture wars and COVID-19 conduct: Christian nationalism, religiosity, and Americans' behavior during the coronavirus pandemic. Journal for the Scientific Study of Religion, 59(3), 405-416.

Pierre, J. (2020). Nudges against pandemics: Sweden's COVID-19 containment strategy in perspective. Policy and Society, 39(3), 478-493.

Reason, J. (1990). Human error. Cambridge University Press.

Reiss, K., \& Bhakdi, S. (2020). Corona fehlalarm? Zablen, daten und bintergründe. Goldegg.

Richey, L. A., \& Budabin, A. (2016). Celebrities in international affairs. Oxford Handbooks Online. https://doi.org/10.1093/oxfordhb/978019993 5307.013.3.

Sergent, K., \& Stajkovic, A. D. (2020). Women's leadership is associated with fewer deaths during the COVID-19 crisis: Quantitative and qualitative analyses of United States Governors. Journal of Applied Psychology, 105(8), $1-13$.

Seyhan, E. (2020). Pandemic powers: Why human rights organizations should not lose focus on civil and political rights. Journal of Human Rights Practice, $12(2), 268-275$.

Spector, B. (2019). Constructing crisis: Leaders, crises and claims of urgency. Cambridge University Press.

Spector, B. (2020). Even in a global pandemic, there is no such thing as a crisis. Leadership, 16(3), 303-310.

't Hart, P. (1993). Symbols, rituals and power: The lost dimensions of crisis management. Journal of Contingencies and Crisis Management, 1(1), 36-50. 
't Hart, P., \& Boin, A. (2001). Between crisis and normalcy: The long shadow of post-crisis politics. In U. Rosenthal, A. Boin, \& L. K. Comfort (Eds.), Managing crises: Threats, dilemmas, opportunities (pp. 28-48). Charles C. Thomas.

The Lancet. (2020). Editorial: The Covid-19 infodemic. The Lancet Infectious Diseases, 20(8), 875.

Van Prooijen, J. W., \& Douglas, K. M. (2017). Conspiracy theories as part of history: The role of societal crisis situations. Memory Studies, 10(3), 323-333.

Vliegenthart, R., \& Damstra, A. (2019). Parliamentary questions, newspaper coverage, and consumer confidence in times of crisis: A cross-national comparison. Political Communication, 36(1), 17-35.

Vos, S. C., \& Buckner, M. M. (2016). Social media messages in an emerging health crisis: Tweeting bird flu. Journal of Health Communication, 21(3), 301-308.

Wilson, S. (2020, April 5). Three reasons why Jacinda Ardern's Covid response has been a master class in crisis leadership. The Conversation. https://theconversation.com/three-reasons-why-jacinda-arderns-corona virus-response-has-been-a-masterclass-in-crisis-leadership-135541.

World Health Organization (WHO). (2020). Coronavirus disease (COVID19) advice for the public: Mythbusters. https://www.who.int/emergencies/dis eases/novelcoronavirus-2019/advice-for-public/myth-busters.

You, M., \& Ju, Y. (2019). Salience of public leaders' "meaning making" in news coverage of a health crisis. Journal of Contingencies and Crisis Management, $27(4), 400-405$.

Open Access This chapter is licensed under the terms of the Creative Commons Attribution 4.0 International License (http://creativecommons.org/licenses/ by $/ 4.0 /$ ), which permits use, sharing, adaptation, distribution and reproduction in any medium or format, as long as you give appropriate credit to the original author(s) and the source, provide a link to the Creative Commons license and indicate if changes were made.

The images or other third party material in this chapter are included in the chapter's Creative Commons license, unless indicated otherwise in a credit line to the material. If material is not included in the chapter's Creative Commons license and your intended use is not permitted by statutory regulation or exceeds the permitted use, you will need to obtain permission directly from the copyright holder.

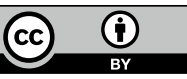

